\title{
Identifikasi Minat Siswa SMA Kelas X Terhadap Mata Pelajaran Fisika
}

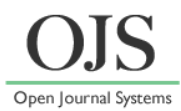

\author{
Diki Chen*, Novita Dwi Putri, Wella Meliza, Yuli Astuti, \\ Langgeng Yoga Wicaksono, Wita Ardina Putri \\ Program Studi Pendidikan Fisika, Universitas Jambi, Jambi 36123 \\ *Email: dikichen012@gmail.com
}

DOI: https://doi.org/10.33369/pendipa.5.1.36-39

\begin{abstract}
The objective of this study was to identify students' interest in Physics in class X MIPA 1 SMA Negeri 1 Adhyaksa, Jambi City. Student interest plays an important role because if students are interested, the student's learning achievement will also be better. Learning interest itself has an influence on student achievement in physics subjects, with interest in learning will help students understand physics material that is quite abstract. The research method used is descriptive quantitative, using a questionnaire instrument to collect data. The questionnaire used was 30 statements with 30 students as respondents. Based on the research results, it was found that 29 students got pretty good results and as many as 1 person got poor results. With these results it shows that class X MIPA 1 already has sufficient interest in physics subjects. Students who have good enough interests allow them to take concrete actions from their interests, while students who have good interests are expected to have a career in science, especially physics.
\end{abstract}

Keywords: Identification; Interest; Physics; Learning achievement; Descriptive quantitative

\begin{abstract}
ABSTRAK
Penelitian ini bertujuan untuk mengidentifikasi minat siswa terhadap mata pelajaran fisika di kelas $\mathrm{X}$ MIPA 1 SMA Negeri 1 Adhyaksa, Kota Jambi. Minat siswa sangat berperan penting karena jika siswa berminat maka prestasi belajar siswa juga akan semakin bagus. Minat belajar sendiri memiliki pengaruh dalam pencapaian prestasi siswa dalam mata pelajaran fisika, dengan adanya minat belajar akan membantu siswa memahami materi fisika yang cukup abstrak. Metode penelitian yang digunakan yaitu kuantitatif deskriptif, dengan menggunakan instrumen angket untuk mengumpulkan data. Angket yang digunakan sebanyak 30 butir pernyataan dengan responden sebanyak 30 siswa. Berdasarkan hasil penelitian didapatkan 29 siswa mendapatkan hasil yang cukup baik dan sebanyak 1 orang mendapatkan hasil yang kurang baik. Dengan hasil tersebut menunjukkan bahwa kelas X MIPA 1 sudah memiliki minat yang cukup terhadap mata pelajara fisika. Siswa yang memiliki minat yang cukup baik memungkinkan untuk melakukan tindakan nyata dari minat yang dimiliki, sedangkan untuk siswa yang memiliki minat yang baik diharapkan dapat berkarir di bidang sains terutama fisika.
\end{abstract}

Kata kunci: Identifikasi; Minat; Fisika; Prestasi Belajar; Kuantitatif Deskriptif

\section{PENDAHULUAN}

Pendidikan merupakan proses pembangunan suatu bangsa dan negara, dengan adanya pendidikan maka diharapakan terciptanya orangorang terpelajar yang nantinya akan berguna dalam pembangunan suatu bangsa atau Negara. Pendidikan ditujukan untuk memperbaiki kualitas kehidupan, serta memperoleh dan menanamkan keterampilan (Kurniawan, et all,
2018). Pendidikan pada dasarnya adalah usaha sadar dan tidak sadar yang dilakukan untuk pengembangan sumber daya manusia terutama peserta didik yang dilakukan dengan cara mengarahkan dan menjadi fasilitator pada proses kegiatan belajar mengajar mereka (Astalini, et all, 2018), tujuan pendidikan di Indonesia ditujukan untuk meningkatkan sumber daya yang dilakukan secara interaktif, inspiratif, dan 
motivatif untuk peserta didik peserta didik (Astalini, et all, 2018). Pendidikan didapatakan oleh setiap warga Negara, hal itu dapat terlihat di UUD 1945 pasal 31 yang menyatakan bahwa setiap warga Negara Indonesia berhak untuk memperoleh pendidikan tanpa membedakan suku, agama, dan ras masing-masing, salah satu proses pendidikan yang sering dijumpai yaitu proses pembelajaran ( Sirait, 2016).

Menurut Putri dan Isnani (2018) Proses belajar merupakan kegiatan utama dalam pendidikan. Proses pembelajaran di SMA 1 Adhyaksa Kota Jambi didapati bahwa siswasiswa tidak terlalu antusias dan bersemangat saat menjawab soal fisika, disinilah tugas seorang guru untuk mencari penyebab yang menjadi dasar anggapan tersebut.

Belajar merupakan proses membangun pengetahuan melalui pengalaman yang berulang. Belajar dapat juga mempengaruhi tingkah laku seseorang, ketika seseorang telah mengalami proses belajar maka aka nada juga yang namanya hasil belajar.

Hasil belajar sangat berkaitan dengan segala sesuatu mengenai perubahan siswa yang dinyatakan dengan skor dalam materi pelajaran tertentu. Dalam artian sempit hasil belajar adalah kemampuan yang diperoleh anak setelah melalui kegiatan belajar, anak yang berhasil dalam belajar adalah yang berhasil dalam mencapai tujuan-tujuan yang telah direncanakannya. Hasil belajar sendiri meliputi: (1) Pemahaman konsep; (2) Keterampilan proses; (3) Sikap siswa (Susanto, 2013).

Minat belajar merupakan faktor yang sangat penting dalam mencapai kesuksesan di segala bidang seperti sepeti studi, kerja, hobi, maupun aktivitas. Dengan tumbuhnya minat maka di dalam diri orang akan timbul rasa semangat dan tertarik untuk melakukan sesuatu, timbal baliknya seseorang tersebut akan lebih tekun dan mendalami, lebih berkonsentrasi, dan tidak mudah jenuh dalam melakukan sesuatu terlebih ke aktivitas yang berulang-ulang. Sekolah sebagai instansi pendidikan m5emiliki peranan yang sangat penting dalam pembetukan minat dan bakat belajar siswa.

Minat belajar bergantung pada faktor-faktor lainnya seperti; perhatian, keingintahuan, motivasi, kebutuhan, dan lain-lain. Minat belajar bukan hanya bergantung dengan keinginan peserta didik tetapi juga dipengaruhi oleh hal-hal diluar peserta didik seperti guru, bahan pelajaran, sarana dan prasarana, ekonomi, dan strategi dan metode yang digunakan guru dalam mengajar. Menurut (Susanto, 2018) Minat belajar siswa sangat bergantung dengan kemampuan guru untuk mengelola kelas. Melihat betapa pentingnya peran guru dalam peningkatan minat siswa, maka diharapkan guru mampu memberikan suatu variasi yang menarik dalam mengajar siswa. Dengan demikian minat adalah kesadaran seseorang yang mendorong untuk memusatkan perhatian dengan disertai perasaan semangat dan puas (Hamdi, 2019). Apabila minat siswa dibangkitkan maka diharapkan siswa dapatt memusatkan konsentrasinya secara penuh pada mata pelajaran tertentu. Lebih lanjut lagi pemusatan konsentrasi tersebut diharapkan dapat membentuk rasa ingin tahu siswa dengan mempelajari dan membuktikan apa yang menjadi pusat perhatiannya

Ciri-ciri minat belajar menurut Slamento (2010) meliputi: (1) Memiliki kecenderungan ingatan yang kuat terhadap sesuatu yang dipelajari; (2) Memiliki rasa suka dan senang terhadap sesuatu yang diminati; (3) Muncul rasa bangga terhadap sesuatu yang diminati; (4) Lebih tertarik dan menyukai apa yang dia minati; (5) Selalu berpartisipasi pada aktivitas yang berhubungan dengan sesuatu yang diminati.

Berdasarkan observasi yang telah dilakukan penulis di SMA 1 Adhyaksa kota jambi, pelajaran fisika dianggap sangat sulit untuk dipahami. Pernyataan tersebut tentunya mendatangkan pertanyaan yaitu "apakah siswasiswa-siswa di kelas X MIPA 1 memiliki minat terhadap pelajaran fisika". Dengan demikian penelitian ini bertujuan untuk mengidentifikasi minat siswa terhadap mata pelajaran khususnya untuk mata pelajaran fisika yang dianggap sebagai sesuatu yang sangat sulit dipelajari.

\section{METODE PENELITIAN}

Penelitian menggunakan metode kuantitatif deskriptif. Penelitian dilakukan di SMA 1 Adhyaksa Kota Jambi pada bulan Oktober s/d November 2020. Sampel penelitian yaitu seluruh anak kelas X MIPA 1 yang berjumlah 30 orang. Instrumen yang digunakan 30 butir pernyataan mengenai minat siswa terhadap pelajaran fisika. 


\section{HASIL DAN PEMBAHASAN}

Penelitian ini dilakukan di SMA 1 Adhyaksa Kota Jambi pada bulan Oktober 2020. Dalam pelaksanaan penelitian diawali dengan penyusunan instrumen seminggu sebelum penelitian, dan bersamaan dengan penyusunan instrumen peneliti juga mengkomunikasikan dan mengobservasi tempat terkait dengan penelitian yang akan dilaksanakan seminggu kemudian. Sebelum menyebarkan angket, peneliti terlebih dahulu mengurus perizinan kepada pihak sekolah dan juga mengatur jadwal untuk penelitian.

Menurut Matondang (2018) minat adalah suatu kecenderungan untuk memperoleh prestasi belajar, minat belajar tumbuh dari siswa yang membuat siswa menjadi senang dslam mengikuti pembelajaran (Putri, et all, 2017). Menurut Prayuga dan Abadi (2019) minat belajar memiliki dua aspek yaitu (1) Aspek kognitif (2) Aspek afektif (3) Aspek psikomotorik, Kedua aspek ini saling berkaitan dimana pengetahuan bisa mempengaruhi sikap siswa dan juga sebaliknya sikap juga bisa mempengaruhi pengetahuan siswa.

Pengambilan data diikuti 30 siswa kelas X Mipa 1, menurut Gulo (2016) skor yang diperoleh dari minat siswa terhadap fisika diklasifikasikan pada tabel berikut.

Tabel 1. Kategori minat siswa

\begin{tabular}{ccc}
\hline Skor & Interval $(\%)$ & Kategori \\
\hline $103-120$ & $\geq 85$ & Sangat Baik \\
$85-102$ & $70-84$ & Baik \\
$67-84$ & $55-69$ & Cukup \\
$49-66$ & $40-54$ & Kurang \\
$30-48$ & $\leq 39$ & Sangat Kurang \\
\hline
\end{tabular}

Berdasarkan hasil analisis maka dapat diketahui tabel distribusi frekuensi perolehan skor minat siswa kelas X MIPA 1 SMA 1 Adhyaksa kota Jambi seperti tabel berikut.

Tabel 2. Frekuensi minat siswa terhadap pelajaran fisika

\begin{tabular}{cccc}
\hline Skor & Mean & F & F $(\%)$ \\
\hline $103-120$ & 78.83 & - & - \\
$85-102$ & 78.83 & 1 & 3.33 \\
$67-84$ & 78.83 & 29 & 96.67 \\
$49-66$ & 78.83 & - & - \\
$30-48$ & 78.83 & - & - \\
\hline
\end{tabular}

Berdasarkan hasil tabel diatas dapat diketahui bahwa siswa-siswa kelas X MIPA 1 memiliki minat yang baik terhadap pelajaran fisika. Dari data dapat dilihat yaitu sebesar 96.67 $\%$ anak dari kelas X MIPA 1 memiliki cukup ketertarikan terhadap mata pelajaran fisika. Ketertarikan untuk mempelajari fisika akan mempengaruhi perkembangan dan pertumbuhan sikap siswa terhadap mata pelajaran fisika. Sikap positif tersebut dapat ditunjukkan dengan ketertarikan siswa mempelajari dan memahami fenomena atau kejadian menarik seputar fisika di kehidupan sehari-hari. Namun tidak semua siswa memiliki ketertarikan yang rendah terhadap mata pelajaran fisika, akan tetapi untuk penelitian ini terlihat bahwa siswa sudah cukup memiliki ketertarikanyaitu sebanyak $96.67 \%$ siswa, dimana untuk hal ini penulis beranggapan bahwa siswa-siswa masih bias dan memiliki kemungkinan untuk berkembang dalam bidang fisika. Namun dalam hal ini siswa juga dapat mengalami kemunduran terhadap ketertarikan siswa, hal ini dapat disebabkan dari guru, temantemannya, dan juga lingkungan sekitarnya. Guru dalam hal ini sebagai pembimbing dan juga pengarah perlu memberikan perhatian lebih kepada siswa-siswanya agar dapat berkembang dengan baikterutama di bidang sains fisika. Selain itu didapatkan juga.

Tabel 3. Distribusi statistik

\begin{tabular}{cc}
\hline & Nilai \\
\hline Mean & 78.83 \\
Modus & 80 \\
Std. Deviasi & 4.57190 \\
\hline
\end{tabular}

Dari Tabel diatas didapatkan nilai mean sebesar 78,83 yang menunjukkan bahwa keseluruhan sampel sudah memiliki minat yang cukup terhadap pelajaran fisika. Modus didapatkan nilai sebesar 80 yang menunjukkan sebagian besar siswa masuk dalam kategori cukup baik. Nilai standar deviasi yang lebih kecil dari mean data menunjukkan data penelitian kurang bervariasi. Berdasarkan hasil penelitian, didapatkan bahwa minat belajar siswa terhadap mata pelajaran fisika sudah cukup baik. Minat belajar tersebut tentunya sangat penting untuk menunjang pembelajaran fisika yang memiliki beberapa materi yang cukup kompleks. Selain itu, dengan 
minat belajar tersebut diharapkan siswa dapat menekuni dan berkarir di bidang fisika nantinya.

\section{KESIMPULAN}

Minat belajar merupakan keadaan siswa memberikan perhatian lebih pada pembelajaran dengan disertai keinginan untuk memahami suatu pelajaran hingga ke fase yang lebih mendalam lagi, minat belajar memiliki pengaruh terhadap hasil belajar siswa. Berdasarkan hasil penelitian dan analisis data didapatkan nilai rata-rata sebesar 78,83 yang dapat menunjukkan bahwa siswa kelas X MIPA 1 SMA 1 Adhyaksa memiliki minat yang cukup baik terhadap pelajaran fisika, akan tetapi dalam hal ini tidak menjamin bahwa siswa tersebut akan menekuni dan juga berkarir dibidang sains fisika.

\section{DAFTAR PUSTAKA}

Astalini, et all. (2018). Identifikasi Sikap Implikasi Sosial Dari IPA, Ketertarikan Menambah Waktu Belajar IPA, dan Ketertarikan Berkarir Di Bidang IPA Siswa SMP Se-Kabupaten Muara Jambi. Jurnal Tarbiyah, 7(2).

Astalini, et all. (2018). Sikap Siswa Terhadap Pelajaran Fisika di SMAN Kabupaten Batanghari. Jurnal Ilmu Pendidikan Fisika, 3(2), 59.

Hamdi, dan Rahim, C., (2019). Analisis Minat Belajar Siswa Terhadap Mata Pelajaran Fisika di SMA Negeri 1 Sakti. Jurnal Sains Riset, 9(3).

Kambuaya, Carlos. (n.d). Pengaruh Motivasi, Minat, Kedisiplinan, Dan Adaptasi Diri Terhadap Prestasi Belajar Siswa Peserta Program Afirmasi Pendidikan Menengah Asal Papua Dan Papua Barat Di Kota Bandung. Social work jurnal, 5(2), 160.

Kurniawan, D. A., et all. (2018). Evaluasi Sikap Siswa SMP Terhadap IPA Di Kabupaten Muaro Jambi. Jurnal Ilmiah DIDAKTIKA, 19(1), 125.
Matondang, Asnawati. (2018). Pengaruh Antara Minat dan Motivasi Dengan Prestasi Belajar. Jurnal Pendidikan Bahasa dan Sastra Indonesia, 2(2), 24.

Nurhasanah, Siti.,dan Sobandi, A . (2016). Minat Belajar Siswa Sebagai Determinan Hasil Belajar Siswa. Jurnal Pendidikan Manajemen Perkantoran. 1(1).

Prayuga, Yugi, dan Abadi, A. P. (2019). Minat Belajar Siswa Dalam Pembelajaran Matematika. Prosiding Seminar Nasional Matematika dan Pendidikan Matematika, 1052.

Putri, Kabela, et all. (2017). Pengaruh Minat Belajar Dan Kecerdasan Emosional Terhadap Prestasi Belajar Siswa Kelas XI IPS SMA NEGERI 1 PRAJEKAN Kabupaten Bondowoso Tahun Ajaran 2016/2017. Jurnal pendidikan ilmu pendidikan, dan ilmu social., 11(1), 67.

Putri, D. T. N., dan Isnani, G. (2015). Pengaruh Minat Dan Motivasi Siswa Terhadap Hasil Belajar Pada Mata Pelajaran Pengantar Administrasi Perkantoran. Jurnal Pendidikan Bisnis Dan Manajemen, 1(2), 118.

Sirait, Erlando. (2016). Pengaruh Minat Belajar Terhadap Prestasi Belajar Matematika. Jurnal Formatif, 6(1).

Slamento. (2010). Belajar dan Faktor-Faktor yang Mempengaruhinya. Jakarta: PT. Rineka Cipta.

Susanto, Haris. (2018). Profesionalisme Guru Dalam Pengelolaan Kegiatan Pembelajaran di Sekolah. Yogyakarta: Deepublish. 